\title{
Population biology of the crab Armases angustipes (Crustacea, Decapoda, Sesarmidae) at Brazilian tropical coast
}

\author{
Marina de Sá Leitão C. de Araújo ${ }^{1,2}$, Deusinete de O. Tenório² \& Daniela da S. Castiglioni ${ }^{3,4}$
}

\author{
1. Departamento de Ciências Exatas e Naturais, Faculdade de Ciências, Educação e Tecnologia de Garanhuns (FACETEG), Universidade de Pernambuco (UPE), \\ Rua Cap. Pedro Rodrigues, 105, São José 55294-902 Garanhuns, PE, Brasil. (corresponding author: mslc.araujo@gmail.com) \\ 2. Museu de Oceanografia Professor Petrônio Alves Coelho, Departamento de Oceanografia (DOCEAN), Universidade Federal de Pernambuco (UFPE), Av. Arquitetura, s/n, \\ Cidade Universitária, 50740-550 Recife, PE, Brasil. (dotmar@globo.com) \\ 3. Departamento de Zootecnia e Ciências Biológicas, Centro Superior de Educação Norte do RS (CESNORS), Universidade Federal de Santa Maria (UFSM), Av. Independência, 3751, \\ Vista Alegre, 98300-000 Palmeira das Missões, RS, Brasil. (danielacastiglioni@yahoo.com.br) \\ 4. Programa de Pós-Graduação em Biodiversidade Animal, Centro de Ciências Naturais e Exatas, Prédio 17, sala 1140-D, Cidade Universitária, Camobi, km 9, Santa Maria, RS, Brasil.
}

\begin{abstract}
The semi terrestrial crabs are important elements of the fauna of coastal regions. The aim of this study was to analyze the population structure of Armases angustipes (Dana, 1852) at estuaries of the Ariquindá River, considered a non impacted area, and Mamucabas River, considered a few impacted area, on the south coast of state of Pernambuco, Brazil. The species occurred in all months of the year. The number of individuals per month varied, being higher in the months of transition between the seasons. This is probably due to significant seasonal variations of air and burrow temperature and burrow salinity. There was no sexual dimorphism in size of A. angustipes in the mangrove of Ariquindá River, but males were larger than females in the mangrove of Mamucabas River. In both estuaries, the sex ratio did not differ from Mendelian proportion, but showed a deviation for females. The analysis of temporal variation in sex ratio showed significant differences in some months of the year. These variations are due to cyclical events that act distinctly on each sex. In both estuaries, size classes of carapace width were equally represented by both sexes. The ovigerous females of A. angustipes occurred only in some months of the year, especially in summer, in both estuaries. Probably the high phytoplankton productivity observed in summer favors the reproductive activity, since these algae serve as food for the larvae. Specimens of the population of Rio Ariquindá are largest and wider than those of Mamucabas River. This fact, associated with the low abundance of crabs and the lower frequency of ovigerous females observed in Mamucabas River, is an indication that this population may be influenced by the environmental impacts that this estuary has received.
\end{abstract}

KEYWORDS. Population dynamics, reproductive period, sesarmid.

RESUMO. Biologia populacional do caranguejo Armases angustipes (Crustacea, Decapoda, Sesarmidae) na costa tropical brasileira. Os caranguejos semiterrestres são importantes elementos da fauna em regiões costeiras. O objetivo do presente trabalho foi analisar a estrutura populacional do caranguejo Armases angustipes (Dana, 1852) nos estuários dos rios Ariquindá, considerada uma área não impactada, e Mamucabas, considerada uma área pouco impactada, localizados no litoral sul do Estado de Pernambuco, Brasil. A espécie ocorreu em todos os meses do ano em ambos os estuários. O número de indivíduos variou entre os meses, sendo maior nos meses de transição entre as estações do ano. Isso, provavelmente, é devido às variações sazonais significativas da temperatura do ar e da toca e da salinidade da toca. Não houve dimorfismo sexual relativo aos tamanhos de A. angustipes no manguezal do Rio Ariquindá, mas os machos foram maiores do que as fêmeas no manguezal do Rio Mamucabas. Em ambos os estuários, a proporção sexual não diferiu da proporção mendeliana, mas mostrou um desvio para as fêmeas. A análise da variação temporal na proporção sexual pôde evidenciar diferenças significativas em alguns meses do ano. Essas variações ocorrem devido a eventos cíclicos que atuam distintamente sobre cada sexo. Em ambos os estuários, as classes de tamanho de largura de carapaça foram igualmente representadas por ambos os sexos. As fêmeas ovígeras de A. angustipes só ocorreram em alguns meses do ano, especialmente no verão, em ambos os estuários. Provavelmente, a maior produtividade primária observada no verão favorece a atividade reprodutiva, uma vez que estas algas servem como alimento para as larvas. Os espécimes da população do rio Ariquindá são mais longos e mais largos do que os do rio Mamucabas. Este fato, associado à menor abundância de caranguejos e menor frequência de fêmeas ovígeras observadas no rio Mamucabas, é um indicativo de que esta população pode estar sendo influenciada pelos impactos ambientais que este estuário tem recebido.

PALAVRAS-CHAVE. Dinâmica populacional, período reprodutivo, sesarmídeo.

The semi terrestrial crabs include a variety of Brachyura with a certain degree of adaptation to life outside water. Their main representatives are the families Ocypodidae, Ucididae, Gecarcinidae, Grapsidae and Sesarmidae. These crabs are important resources for littoral environments, both ecological and economically (MACIEL \& ALVES, 2009). By removing and ingesting vegetal and animal parts, as well as organic particles in the substrata, they act in the cycling of nutrients. On the other hand, many vertebrates as fishes and birds feed on these crabs (Cowen, 1986; Hemmi et al., 2006). Besides, many coastal communities capture crabs for consume and selling, having this activity as their main source of income (MACIEL \& Alves, 2009).
The sesarmid crabs were previously included in the Sesarminae, a subfamily of the Grapsidae (Melo, 1996). After some recent revisions, the family Sesarmidae was accepted (MARTIN \& DAVIS, 2001; NG et al., 2008). Their representatives are characterized by presenting a hairy groove in the exposed side of the third maxilipod, while the Grapsidae doesn't have this characteristic (Melo, 1996). Among the genera included in this family, one of the most characteristic is Armases Abele, 1992. Representatives of this genus are found in the marine, freshwater and terrestrial environments (Schubart \& Diesel, 1998). According to Melo (1996), stands out the species Armases angustipes (Dana, 1852), a small crab distributed along the West coast of the Atlantic Ocean, in Mexico, Antilles and Brazil (from 
Ceará to Santa Catarina States). It is found in the margins of estuaries, as well as in rocky littoral and bromeliads (Melo, 1996).

Bioecology studies on terrestrial and semi terrestrial Brachyura on the Brazilian coast were mainly accomplished with species of socio-economic importance, as Ucides cordatus (Linnaeus, 1763) (Ucididae) (Ivo et al., 1999; Góes et al., 2000; Alves \& Nishida, 2003; Araújo \& Calado, 2008; Oliveira et al., 2013), Cardisoma guanhumi Latreille, 1828 (Gecarcinidae) (BотеLно et al., 2001), Goniopsis cruentata (Latreille, 1803) (Grapsidae) (SAntos et al., 2001; Santos \& Botelho, 2002) and Plagusia depressa (Fabricius, 1775) (Plagusiidae) (FreitAS \& Santos, 2002), as well as species of no economic relevance but ecologically importance, as Uca (Minuca) burgersi Holthuis, 1967 (Ocypodidae) (Benettr et al., 2007), Uca (Uca) maracoani (Latreille, 1802) (BENEDETto \& Masunari, 2009), Uca (Minuca) rapax (Smith, 1870) (CASTIGLioni et al., 2006), Uca (Minuca) thayeri Rathbun, 1900 (Costa \& Negreiros-Fransozo, 2003; Bezerra \& Matthews-CAsCon, 2007), Uca (Minuca) victoriana von Hagen, 1987 (CASTIGLiOn et al., 2011a) and Sesarma rectum Randall, 1840 (Sesarmidae) (CASTIGLIONI et al., 2011b), for example. Such studies are fundamental to understand the ecological stability of natural populations (ARAÚJo et al., 2012a) and to create management plans for exploited species.

Some studies have also addressed the effects of environmental impacts on the population of crabs. The cutting of trees and the deposition of solid wastes on mangroves exerted a negative impact on the abundance of Goniopsis cruentata (Menezes et al., 2012). On the other hand, some impacts may benefit the population of mangrove crabs; the organic matter from the pollution can be a food resource to fiddler crabs, as observed for Uca burgersi and $U$. thayeri by BENETTI \& NeGREIROS-Fransozo (2004) and ARAúso et al. (2012b), respectively.

The species Armases angustipes was studied regarding its larval development (ANGER et al., 1990) and growth (KowalCZuK \& MASUNARI, 2000a). Some remarks on the species distribution and habitat can be found at Coelno (1965/1966), Coelho \& Ramos-Porto $(1981,1995)$. The only study dealing with the population biology of this species was accomplished in the south of Brazil, a temperate area (KowALCZUK \& MASUNARI, 2000b). Besides, these studies were accomplished in rocky substrate. Thus, no information on the population biology of this species in Brazilian mangroves is available. The aim of this work was to compare the population structure of A. angustipes at the mangroves of the Ariquindá River, considered a non impacted area, and Mamucabas River, considered an impacted area, South of state of Pernambuco, Northeast Brazil.

\section{MATERIALS AND METHODS}

Description of the area. The state of Pernambuco is located at northeast Brazil ( $07^{\circ} 32^{\prime} 00^{\prime \prime}$ and $08^{\circ} 55^{\prime} 30^{\prime \prime}$ 'S; $34^{\circ} 48^{\prime} 35^{\prime \prime}$ and $\left.41^{\circ} 19^{\prime} 54^{\prime \prime} \mathrm{W}\right)$. The region has a climate within the As' type of Köppen system, i.e. hot and humid with rains in the autumn and winter (MourA \& Passavante, 1995). The study areas area located at the South of Pernambuco: the mangroves of Ariquindá and Mamucabas Rivers, Municipality of Tamandaré (Fig. 1). The Ariquindá River was considered non-impacted, while the Mamucabas River was considered impacted. Despite of both rivers being considered non polluted (IBAMA, 1989; GREGo et al., 2009), during the samples of A. angustipes some anthropic impacts were observed in the mangrove of Mamucabas River, as it will be explained later.

The Ariquindá River is inserted at the Guadalupe Environmental Preservation Area. It is considered an important component of Formoso River basin (CPRH, 1999), and one of the last non-polluted rivers of state of Pernambuco. The mangrove area chosen for the crabs' samplings is located near the confluence of Ariquindá and Formoso rivers, at Carneiros Beach, and its vegetation is mainly composed by Rhizophora mangle $\mathrm{L}$. (Rhizophoraceae), Laguncularia racemosa (L.) Gaertn. f. (Combretaceae) and, less frequently, Avicennia schaueriana Stapf and Leechman ex Moldenke (Acanthaceae). The substratum was visually characterized as muddy sand.

The Mamucabas River rises at the west of the Saltinho Biological Reserve, being dammed after entering in the Reserve, forming a reservoir that supplies the municipality of Tamandaré. It meets the Ilhetas River and together they disembogue (CPRH, 2003). It is considered an impacted estuary due to the damming and the housing occupation in the surrounding areas (SANTOS et al., 2001), with great deposition of waste and deforestation (ARAúJo et al., 2012b,c). In some previous studies performed on the Mamucabas River, considerable alterations were observed on the biological properties of crustacean species. In the case of $U$. thayeri, males and females of Mamucabas mangrove reached sexual maturity at sizes higher than those of Ariquindá mangrove, indicating that the population of this species from the Mamucabas River is benefiting from the increased availability of organic matter from pollution (ARAúJo et al., 2012b). In the species $U$. cordatus, the condition factor was significantly lower at Mamucabas River, indicating the lower health of the specimens of this estuary (ARAúso et al., 2012c). The mangrove area chosen for the crabs' samplings is located near the confluence of Mamucabas and Ilhetas Rivers, at the Harbor Mouth, and its vegetation is mainly composed by L. racemosa, $R$. mangle and, less frequently, Avicennia schaueriana. The substratum was visually characterized as muddy sand.

Samplings procedures. Monthly, individuals of A. angustipes were manually collected from April 2008 to March 2009, always at low tide during 30 minutes by one person, in one area of mangrove forest at each estuary (the same area every month, with $20 \mathrm{~m}^{2}$ ). They were sampled during the day in burrows and under fallen coconut leaves. The following abiotic data were obtained in situ: air and 


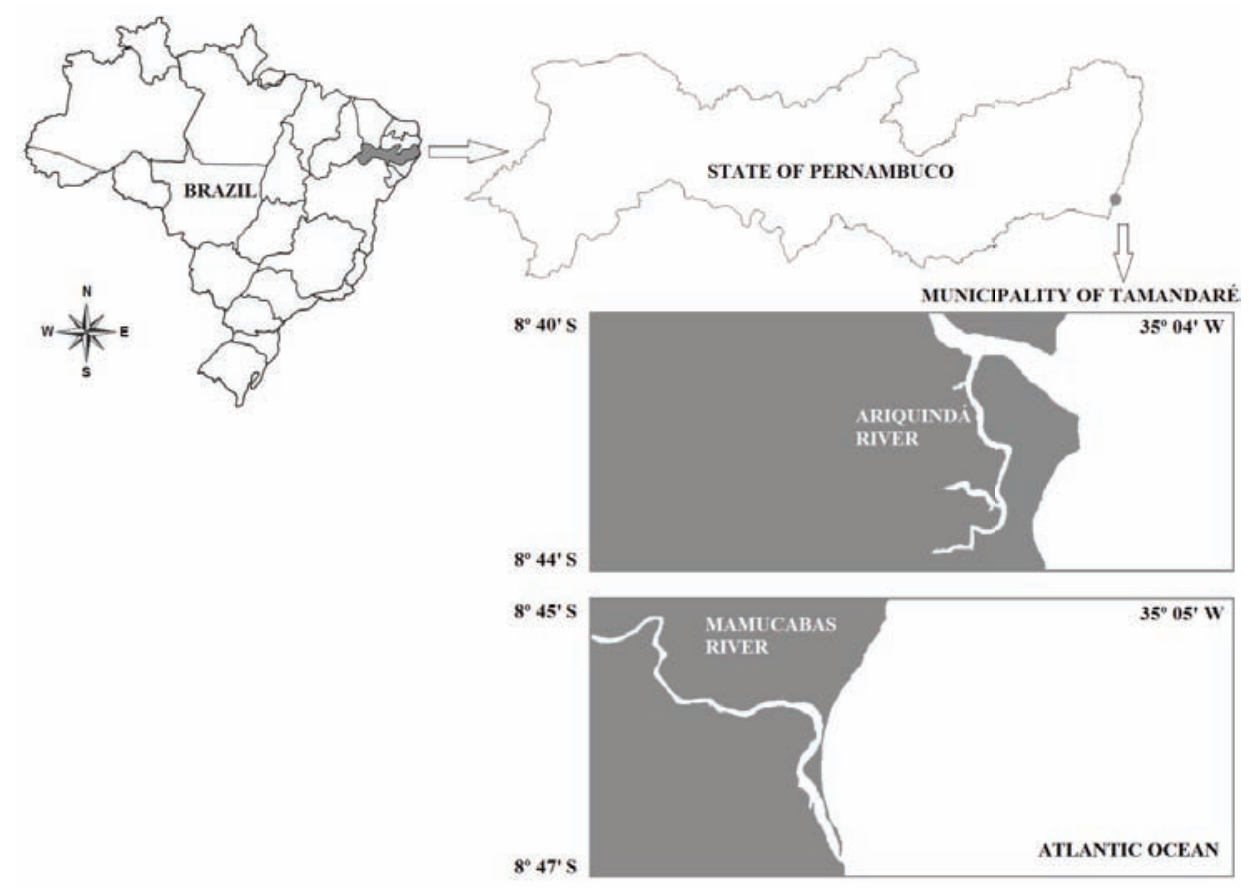

Fig. 1. Map of the study area, at Ariquindá and Mamucabas Rivers, state of Pernambuco, northeast Brazil.

burrow temperature (with a thermometer), burrow and river salinity (salinometer). The crabs were anesthetized in ice and sacrificed with alcohol $70 \%$ concentrated. Additional abiotic data (rainfall, atmospheric pressure, relative humidity, sunlight and wind speed) of the region during the sampling months were obtained through the Sistema Nacional de Dados Ambientais (SINDA) of the nearest meteorological station (Municipality of Rio Formoso).

Laboratory procedures. At laboratory, each crab was sexed (based on the abdomen and pleopods morphology) and measured at the carapace width $(\mathrm{CW})$ and carapace length $(\mathrm{CL})$ with a vernier caliper (precision of $0.01 \mathrm{~mm}$ ). The ovigerous condition of the females was noted. The individuals were discarded after the study.

Data analyses. The mean ( \pm standard deviation) values of each abiotic variable were obtained by periods of the year: dry period from September to February and rainy period from March to August. A Student $t$ test was applied to compare the abiotic data between dry and rainy periods. A Mann-Whitney-Wilcoxon $U$ test was applied to compare the temperature and salinity between the environment and the burrows (ZAR, 1996).

The monthly abundance of $A$. angustipes was graphically plotted. The minimum, mean ( \pm standard deviation) and maximum values of the $\mathrm{CW}$ and $\mathrm{CL}$ were estimated. The Student $t$ test was applied to check for significant differences in the means of CW and CL between males and females, for each estuary. A comparison of the size (CW and CL) of males and females between the estuaries was also performed through a Student $t$ test (ZAR, 1996).

Individuals of each sex were grouped into two ageclasses: juvenile and adult based on the biometric data, through an analysis of K-means clustering, followed by a bivariate discriminant analysis (SAMPEDRo et al., 1999;
AraúJo et al., 2012d).

The sex ratio was analyzed for the whole sampling period and for months, dividing the number of females by the number of males, and the Chi-square test $\left(\chi_{\text {tabled }}^{2}=3.84\right)$ was applied to verify if the sex ratio deviates significantly for the expected proportion $\left(1 \delta^{\lambda}: 1\right.$ ) $)(\mathrm{ZAR}, 1996)$. The animals were grouped into size classes with amplitude of $1.5 \mathrm{~mm}$ (Sturges, 1926), by sex. The $\mathrm{c}^{2}$ test was applied to check for significant differences in the sex ratio by each size classes (ZAR, 1996). These classes were graphically represented. The mode was estimated from the midpoint of the range shift. The distribution was tested through the Shapiro-Wilk test (ZAR, 1996), and classified according to the number of modes in: unimodal, bimodal or polimodal (Araúso et al., 2012a).

The growth of $A$. angustipes was described for each sex by the allometric equation $y=a x^{b}$ (HuXLeY, 1950). The CW was considered the independent variable and related to the CL, the dependent one. The type of growth was established by the value of the constant $b$, which can be isometric $(b=1)$, positive allometric $(b>$ $1)$ or negative allometric $(b<1)$. The evaluation of the statistical significance of $b$ in relation to the unity was accomplished with a $t$ test. To compare the growth of males and females, the intercepts $a$ and the coefficients $b$ were tested through an analysis of covariance (ANCOVA) (CASTIGLIONi et al., 2011b).

The reproductive period was determined based on the monthly abundance of ovigerous females, and classified according to Sastry (1983) and Pinheiro \& Fransozo (2002) as: seasonal (ovigerous females in only some months or seasons), continuous (ovigerous females in all months of the year with similar intensity) or seasonal-continuous (ovigerous females in all months of the year, but with 
distinguishable peak of abundance in some months or seasons).

The correlation of the abiotic factors with the abundance of the crabs was evaluated by the Pearson's coefficient ( $r$ ). According to the values of $r$, the correlation was classified as: $0=$ null; $0<0.3=$ weak; $0.3<0.6=$ regular; $0.6<0.9=$ strong; $0.9<1=$ very strong; and $1=$ full or perfect. All statistical analyses were accomplished for each estuary at $\alpha=0.05$ (ZAR, 1996).

\section{RESULTS}

Abiotic data. The meteorological data from the nearest meteorological station are presented in Table I. It could be noticed that each variable has fluctuated during the year, but no significant differences were observed between dry and rainy periods for rainfall $(t=-0.25 ; p=$ $0.80)$, atmospheric pressure ( $t=-0.88 ; p=0.39$ ), relative humidity $(t=0.36 ; p=0.72)$, sunlight $(t=0.24 ; p=0.81)$ and wind speed $(t=0.92 ; p=0.39)$.

The abiotic data from the in situ measurements at the mangrove of Ariquindá River are presented in Table II. Each abiotic variable has fluctuated during the year, and significant differences were observed between dry and rainy periods for air temperature $(t=-2.52 ; p=0.01)$, burrow temperature $(t=-3.07 ; p=0.01)$ and burrow salinity $(t=-3.70 ; p=0.01)$, with these variables being higher in the dry period. Despite of its wide oscillation, the river salinity did not differ significantly between periods $(t=$ $-1.81 ; p=0.13$ ).

The abiotic data from the in situ measurements at Mamucabas River are presented in Table II. It could be reported that each abiotic variable has fluctuated during the year, and significant differences were observed between dry and rainy periods for air temperature $(t=-3.07 ; p=$ $0.01)$, burrow temperature $(t=-2.78 ; p=0.01)$ and burrow salinity $(t=-3.95 ; p=0.01)$, with these variables being higher in the dry period. Despite of its wide oscillation, the river salinity did not differ significantly between periods $(t=0.95 ; p=0.36)$.

Comparing the abiotic data from the burrows and the environment, the burrow temperature is significantly lower than the air temperature (Ariquindá: $U=28.00$; Mamucabas: $U=40.00)(p<0.05)$. On the other hand, the salinity from the burrow water is significantly higher than the salinity of the river water (Ariquindá: $\mathrm{U}=32.00$; Mamucabas: $\mathrm{U}=15.50)(p<0.05)$.

Comparing both mangroves, no significant differences between the areas were observed in the air $(\mathrm{t}$ $=0.17 ; p=0.86)$ and burrow temperature $(\mathrm{t}=-0.40 ; p$ $=0.68)$. However, significant differences were observed regarding the river $(\mathrm{t}=5.73 ; p=0.01)$ and burrow salinity $(\mathrm{t}=3.92 ; p=0.01)$.

Population biology of Armases angustipes at the mangrove of Ariquindá River. A total of 464 individuals of A. angustipes were sampled, being 213 males and 251 females (33 ovigerous). They were collected in all sampling months, with values of abundance oscillating throughout the year. The higher values were found from July to December 2008, i.e., in the end of the dry period and the beginning of the rainy one (Tab. III). The total sex-ratio $\left(0.85 \delta^{\lambda}: 1\right.$ 우 $)$ did not vary significantly from the expected $\left(1 \hat{\delta}^{\hat{1}}: 1\right.$ \% $)\left(\chi^{2}\right.$ $=3.11 ; p>0.05)$, however, it can be noticed a deviation to the females. The only month where significant difference was observed in the sex ratio was October 2008, when females were more abundant $\left(0.48{ }^{\lambda}: 1\right.$ 古; $\chi^{2}=4.90 ; p<$ 0.05) (Tab. III).

Males showed CW varying from 4.56 to $19.14 \mathrm{~mm}$ $($ mean $\pm \mathrm{sd}=11.53 \pm 3.58 \mathrm{~mm})$. In females, the $\mathrm{CW}$ varied from 3.60 to $18.74 \mathrm{~mm}$ (mean $\pm \mathrm{sd}=11.15 \pm 5.29 \mathrm{~mm}$ ). Males showed CL varying from 4.16 to $18.28 \mathrm{~mm}$ (mean \pm $\mathrm{sd}=11.43 \pm 3.43 \mathrm{~mm}$ ). In the females, the $\mathrm{CL}$ varied from 3.99 to $18.12 \mathrm{~mm}$ (mean $\pm \mathrm{sd}=10.94 \pm 3.83 \mathrm{~mm}$ ). There was no sexual dimorphism in the $\mathrm{CW}(t=1.97 ; p=0.06)$ and CL $(t=1.10 ; p=0.27)$ between males and females.

Both juveniles and adults were sampled at the mangrove of Ariquindá River. The largest juvenile male had $\mathrm{CW}=10.69$ and $\mathrm{CL}=9.84$, while the smallest adult male had CW $=10.58$ and $C L=9.85$. The largest juvenile female had $\mathrm{CW}=9.41$ and $\mathrm{CL}=8.57$, while the smallest adult female had $\mathrm{CW}=9.35$ and $\mathrm{CL}=8.12$.

The frequency distribution by $\mathrm{CW}$ classes was not normal for both sexes $(\mathrm{W}=0.98$ and $\mathrm{W}=0.95$ for males and females, respectively; $p<0.05$ ). The distribution of males was unimodal (at $14.25 \mathrm{~mm}$ ), but with a tendency to bimodality at $9.75 \mathrm{~mm}$, while females showed bimodal distribution (at 6.75 and $14.25 \mathrm{~mm}$ ) (Fig. 2). Both sexes were equally represented in each size class $(p>0.05)$, except at $3.0+4.5 \mathrm{~mm}$, where only females were found, and at $6.0+7.5 \mathrm{~mm}$, where females were more frequent than males $\left(\chi^{2}=10.96, p<0.05\right)$ (Fig. 2).

The relationship CL vs. CW showed a positive allometric growth for both males and females $(p<0.05)$. The ANCOVA revealed that both intercepts $(t=1.10)$ and coefficients $(t=-1.39)$ did not differ between the sexes ( $p$ $>0.05$ ), i.e., males and females exhibit similar patterns of growth for this relation (Fig. 3).

Thirty three ovigerous females were sampled, which represents $13.14 \%$ of the total sampled females. Their occurrence was restricted to some months of the year: April to July 2008 and January to March 2009 (Tab. III). Thus, they were more frequent at the autumn and summer, and their reproduction can be characterized as seasonal.

The correlation matrix showed that the atmospheric pressure is the environmental factor that most influences the abundance of A. angusipes, showing a negative correlation $(r=-0.75)$, followed by the river salinity $(r=0.58)$ and relative humidity ( $r=-0.58)$ (Tab. IV).

Population biology of Armases angustipes at the mangrove of Mamucabas River. A total of 199 individuals of A. angustipes were collected, being 90 males and 109 females (three ovigerous). They were collected in all sampling months, with values of abundance oscillating throughout the year. The higher values were found in May 
Tab. I. Abiotic data (rainfall, atmospheric pressure, relative humidity, sunlight and wind speed) by sampling months and periods of the year, at Rio Formoso meteorological station, state of Pernambuco, northeast Brazil (sd, standard deviation).

\begin{tabular}{|c|c|c|c|c|c|}
\hline \multirow[b]{2}{*}{ Data/Month } & \multicolumn{5}{|c|}{ Rio Formoso meteorological station } \\
\hline & $\begin{array}{l}\text { Rainfall } \\
\text { (mm) }\end{array}$ & $\begin{array}{c}\text { Atmospheric pressure } \\
(\mathrm{mB})\end{array}$ & $\begin{array}{c}\text { Relative humidity } \\
(\%)\end{array}$ & $\begin{array}{l}\text { Sunlight } \\
\left(\mathrm{MJ} / \mathrm{m}^{2}\right)\end{array}$ & $\begin{array}{c}\text { Wind speed } \\
(\mathrm{m} / \mathrm{s})\end{array}$ \\
\hline \multicolumn{6}{|c|}{ Rainy period } \\
\hline Apr & 189.40 & 903.05 & 84.53 & 21.29 & 25.84 \\
\hline May & 229.38 & 886.46 & 78.17 & 18.40 & 23.55 \\
\hline Jun & 5.69 & 868.04 & 70.45 & 17.73 & 22.09 \\
\hline Jul & 34.84 & 856.09 & 66.60 & 17.09 & 24.79 \\
\hline Aug & 100.74 & 855.99 & 58.86 & 15.50 & 25.04 \\
\hline Mar & 8.60 & 896.08 & 84.06 & 18.28 & 25.77 \\
\hline Mean \pm sd & $94.77 \pm 95.98$ & $877.62 \pm 20.44$ & $73.78 \pm 10.26$ & $18.05 \pm 1.91$ & $24.51 \pm 1.45$ \\
\hline \multicolumn{6}{|c|}{ Dry period } \\
\hline Sep & 40.90 & 852.20 & 59.46 & 18.80 & 24.35 \\
\hline Oct & 253.40 & 852.12 & 63.94 & 18.18 & 22.29 \\
\hline Nov & 156.08 & 852.59 & 80.51 & 20.92 & 23.12 \\
\hline Dec & 12.37 & 870.55 & 84.84 & 18.81 & 25.43 \\
\hline Jan & 7.71 & 885.65 & 82.03 & 12.83 & 15.57 \\
\hline Feb & 11.32 & 893.04 & 85.74 & 16.75 & 26.84 \\
\hline Mean \pm sd & $80.30 \pm 101.8$ & $867.69 \pm 18.35$ & $76.09 \pm 11.39$ & $17.71 \pm 2.74$ & $22.93 \pm 3.95$ \\
\hline
\end{tabular}

Tab. II. Abiotic data (air temperature, river salinity, burrow temperature and burrow salinity) by sampling months and periods of the year, at the mangroves of Ariquindá and Mamucabas Rivers, state of Pernambuco, northeast Brazil (temp., temperature; sd, standard deviation).

\begin{tabular}{|c|c|c|c|c|c|c|c|c|}
\hline \multirow{2}{*}{$\begin{array}{l}\text { Data/ } \\
\text { Month }\end{array}$} & \multicolumn{4}{|c|}{ Ariquindá River } & \multicolumn{4}{|c|}{ Mamucabas River } \\
\hline & $\begin{array}{c}\text { Air temp. } \\
\left({ }^{\circ} \mathrm{C}\right)\end{array}$ & River salinity & $\begin{array}{c}\text { Burrow temp. } \\
\left({ }^{\circ} \mathrm{C}\right)\end{array}$ & Burrow salinity & $\begin{array}{c}\text { Air temp. } \\
\left({ }^{\circ} \mathrm{C}\right)\end{array}$ & River salinity & $\begin{array}{c}\text { Burrow temp. } \\
\left({ }^{\circ} \mathrm{C}\right)\end{array}$ & Burrow salinity \\
\hline & \multicolumn{8}{|c|}{ Rainy period } \\
\hline Apr & 29.80 & 15.00 & 27.45 & 22.50 & 30.58 & 12.00 & 28.60 & 20.25 \\
\hline May & 28.80 & 11.00 & 28.30 & 14.75 & 29.85 & 15.00 & 27.98 & 15.25 \\
\hline Jun & 30.13 & 12.00 & 26.83 & 25.50 & 29.25 & 17.00 & 28.08 & 12.00 \\
\hline Jul & 28.85 & 28.00 & 26.03 & 30.50 & 26.10 & 2.00 & 25.85 & 5.25 \\
\hline Aug & 24.93 & 24.00 & 26.27 & 24.75 & 24.35 & 3.00 & 25.53 & 14.50 \\
\hline Mar & 32.85 & 26.00 & 30.83 & 27.25 & 31.85 & 10.00 & 31.03 & 21.50 \\
\hline \multirow[t]{2}{*}{ Mean \pm sd } & $29.23 \pm 2.57$ & $19.33 \pm 7.53$ & $27.62 \pm 1.78$ & $24.21 \pm 5.35$ & $28.66 \pm 3.07$ & $9.83 \pm 6.18$ & $27.84 \pm 2.12$ & $14.79 \pm 7.37$ \\
\hline & \multicolumn{8}{|c|}{ Dry period } \\
\hline Sep & 30.80 & 24.00 & 28.75 & 29.25 & 29.38 & 15.00 & 27.35 & 21.00 \\
\hline Oct & 29.93 & 25.00 & 28.35 & 29.25 & 30.90 & 0.00 & 29.33 & 22.50 \\
\hline Nov & 29.95 & 23.00 & 28.13 & 26.75 & 31.95 & 8.00 & 30.00 & 22.25 \\
\hline Dec & 30.28 & 26.00 & 28.38 & 29.50 & 30.98 & 6.00 & 28.13 & 23.00 \\
\hline Jan & 31.08 & 25.00 & 29.13 & 29.25 & 31.58 & 10.00 & 29.75 & 24.75 \\
\hline Feb & 31.83 & 27.00 & 30.73 & 28.25 & 30.65 & 0.00 & 30.83 & 18.00 \\
\hline Mean \pm sd & $30.64 \pm 0.74$ & $25.00 \pm 1.41$ & $28.91 \pm 0.96$ & $28.71 \pm 1.05$ & $30.90 \pm 1.63$ & $6.50 \pm 5.35$ & $29.23 \pm 1.35$ & $21.92 \pm 2.07$ \\
\hline
\end{tabular}

Tab. III. Number of males, females (total and ovigerous) and total individuals of Armases angustipes (Dana, 1852), and results of the $\chi^{2}$ by sampling months, at the mangrove of Ariquindá River, state of Pernambuco, northeast Brazil (* = significant difference at 5\%).

\begin{tabular}{|c|c|c|c|c|c|}
\hline \multirow{2}{*}{ Month } & \multirow{2}{*}{$0^{2}$} & \multicolumn{2}{|c|}{ 우 } & \multirow{2}{*}{ Total } & \multirow{2}{*}{$\chi^{2}$} \\
\hline & & Total & Ovigerous & & \\
\hline Apr/2008 & 14 & 9 & 4 & 27 & 0.04 \\
\hline May/2008 & 14 & 14 & 6 & 34 & 1.06 \\
\hline Jun/2008 & 16 & 16 & 4 & 36 & 0.44 \\
\hline $\mathrm{Jul} / 2008$ & 22 & 21 & 4 & 47 & 0.19 \\
\hline Aug/2008 & 21 & 26 & 0 & 47 & 0.53 \\
\hline $\mathrm{Sep} / 2008$ & 16 & 26 & 0 & 42 & 2.38 \\
\hline Oct $/ 2008$ & 13 & 27 & 0 & 40 & $4.90 *$ \\
\hline Nov/2008 & 19 & 19 & 0 & 38 & 0 \\
\hline Dec/2008 & 28 & 18 & 0 & 46 & 2.17 \\
\hline Jan/2009 & 20 & 9 & 7 & 36 & 0.44 \\
\hline $\mathrm{Feb} / 2009$ & 16 & 14 & 6 & 36 & 0.44 \\
\hline Mar/2009 & 14 & 19 & 2 & 35 & 1.4 \\
\hline Total & 213 & 218 & 33 & 464 & 3.11 \\
\hline
\end{tabular}


2008, and from December 2008 to March 2009, i.e., in the beginning of the rainy period and the beginning of the dry one (Tab. V). The total sex-ratio $\left(0.83 \delta^{\wedge}: 1\right.$ i $)$ did not vary significantly from the expected $\left(\chi^{2}=1.81 ; p>0.05\right)$, however, it can be noticed a deviation to the females. No month showed significant difference in the sex ratio $(p>$ 0.05) (Tab. V).

Males showed CW varying from 4.05 to $15.45 \mathrm{~mm}$ (mean $\pm \mathrm{sd}=8.42 \pm 2.62 \mathrm{~mm}$ ). In females, the $\mathrm{CW}$ varied from 4.06 to $14.56 \mathrm{~mm}$ (mean $\pm \mathrm{sd}=7.61 \pm 2.23 \mathrm{~mm}$ ). Males showed CL varying from 3.41 to $14.09 \mathrm{~mm}$ (mean \pm $\mathrm{sd}=7.62 \pm 2.42 \mathrm{~mm}$ ). In the females, the $\mathrm{CL}$ varied from 3.71 to $13.33 \mathrm{~mm}$ (mean $\pm \mathrm{sd}=6.82 \pm 1.89 \mathrm{~mm}$ ). There was sexual dimorphism in the $\mathrm{CW}(t=2.36 ; p=0.02)$ and CL $(t=2.35 ; p=0.02)$ between males and females, with males being larger and wider than females.

Both juveniles and adults were sampled at the mangrove of Mamucabas River. The largest juvenile male had $\mathrm{CW}=8.21$ and $\mathrm{CL}=7.12$, while the smallest adult male had $\mathrm{CW}=8.35$ and $\mathrm{CL}=7.30$. The largest juvenile female had $\mathrm{CW}=7.50$ and $\mathrm{CL}=6.64$, while the smallest adult female had $\mathrm{CW}=7.77$ and $\mathrm{CL}=7.06$.

The frequency distribution by $\mathrm{CW}$ classes was not normal for both sexes $(\mathrm{W}=0.96$ and $\mathrm{W}=0.94$ for males and females, respectively; $p<0.05$ ). The distribution of both males and females was unimodal (at $6.75 \mathrm{~mm}$ ) (Fig. $4)$. Both sexes were equally represented in each size class $(p>0.05)$, except at $6.0+7.5 \mathrm{~mm}$, where females were more frequent than males $\left(\chi^{2}=4.41, p<0.05\right)$, and at $15.0+16.5$ and $16.5+18.0 \mathrm{~mm}$, where only males were found (Fig. 4).

The relationship CL vs. CW showed a positive allometric growth for both males and females $(p<0.05)$. The ANCOVA revealed that both intercepts $(t=0.28)$ and coefficients $(t=0.56)$ did not differ between the sexes $(p$ $>0.05$ ), i.e., males and females exhibit similar patterns of growth for this relation (Fig. 5).

Only three ovigerous females were sampled, which represents $2.75 \%$ of the total sampled females. Their occurrence was restricted to some months of the year: January to March 2009 (Tab. V). Thus, they were more frequent at the summer, and their reproduction can be characterized as seasonal.

The correlation matrix showed that the burrow salinity is the environmental factor that influences the most the abundance of $A$. angusipes, showing a negative correlation ( $r=-0.41)$ (Tab. VI). However, it could be noticed that at Mamucabas River, the abundance is less influenced by the abiotic factors when compared to Ariquindá River.

Comparison of the body size of Armases angustipes between mangroves. The student $t$ test revealed significant differences of the size between the populations. Males of the mangrove of Ariquindá River were significantly larger and wider than those of the mangrove of Mamucabas River ( $t=9.18 ; p=0.01$ and $t=9.48 ; p=0.01$, respectively). Additionally, females of the mangrove of Ariquindá River were also significantly larger and wider than those of the mangrove of Mamucabas River $(t=10.87 ; p=0.01$ and $t$ $=11.92 ; p=0.01$, respectively).

\section{DISCUSSION}

In the present study, it was observed that the temperature and salinity of the burrows were significantly lower in the rainy season, at the mangroves of Ariquindá and Mamucabas Rivers. The decrease in these values is probably related to the greater rainfall in this period (Passavante \& Feitosa, 2004). Regarding burrow temperature, it was also observed that it is lower than air temperature. Besides providing protection to crabs, the burrows reduce temperature extremes and serve as water reservoir (HERREID, 1963; Araújo \& CALAdo, 2011). Burrow water was significantly more saline than river water. This is probably due to the evaporation of water from burrows when they are exposed at low tide, as well as due to the elimination of salt by mangrove trees (PASSIOURA et al., 1992; Thongtham \& Kristensen, 2003; Araújo \& Calado, 2011).

At the mangroves of Ariquindá and Mamucabas Rivers, A. angustipes occurred in all months of the year, as well as observed by KowALCZUK \& MASUNARI (2000b) at the rocky littoral of Farol Island, state of Paraná, south of Brazil. On the other hand, CALADO \& LACERDA (1993) did not observe this species in all months of the year at the rocky littoral of Calhetas, state of Pernambuco. The study of CALADO \& LACERDA (1993) does not deal specifically on the population biology of A. angustipes. It describes the community of Decapoda and Isopoda in general, and probably there was no specific sampling on the cited species. On the other hand, in the study of KowALCZuCK \& MASUNARI (2000b), the samplings were species-specific. In the present study, the number of individuals varied per month, being significantly higher in transitional months between the seasons. That is probably due to the significant seasonal variations of the air and burrows temperatures and burrow salinity. KowalczuK \& Masunari (2000b) observed a lower number of these crabs during the autumn and winter, possibly due to the low temperatures observed during these seasons in Southern Brazil. We believe that in low temperatures, the crabs may exhibit a cryptic habit.

The sizes of CW observed in the present study are very similar to those obtained by Kowalczuk \& Masunari (2000b). These small crabs do not reach large sizes of CW. There was no sexual dimorphism in the $\mathrm{CW}$ of Armases angustipes at the mangrove of Ariquindá River, as well as observed by KowaLczuK \& Masunari (2000b) for the same species. However, that is not the pattern for Crustacea, Infraorder Brachyura. Generally, males are significantly larger than females, as observed in the present study at the mangrove of Mamucabas River, in Callinectes danae Smith, 1869 (Portunidae) (Araúso et al., 2012a), Goniopsis cruentata (LiRA et al., 2012), Sesarma rectum (CASTIGlioni et al., 2011) and Ucides cordatus (CASTIGLIONI 
Tab. IV. Correlation of the abiotic data (rainfall air, atmospheric pressure, relative humidity, sunlight, wind speed, air temperature, river salinity, burrow temperature, burrow salinity) with the abundance of Armases angustipes (Dana, 1852), at the mangrove of Ariquindá River, state of Pernambuco, northeast Brazil (atm., atmospheric; temp., temperature; sign., significance; *, significant difference at 5\%; ns, no significant difference; correl., correlation).

\begin{tabular}{lccccccccc}
\hline \multirow{2}{*}{ Correl. } & \multicolumn{8}{c}{ Abiotic data } \\
\cline { 2 - 10 } & Rainfall & Atm. pressure & Relative humidity & Sunlight & Wind speed & Air temp. & River salinity Burrow temp. Burrow salinity \\
\hline$r$ & -0.29 & -0.75 & -0.58 & -0.30 & 0.10 & -0.45 & 0.58 & -0.37 & 0.49 \\
$\mathrm{~T}$ & -0.94 & -3.59 & -2.23 & -1.00 & 0.31 & -1.58 & 2.27 & -1.28 & 1.80 \\
$\mathrm{P}$ & 0.37 & 0.00 & 0.04 & 0.34 & 0.76 & 0.14 & 0.04 & 0.23 & 0.10 \\
Correl. & weak & strong & regular & regular & weak & regular & regular & regular & regular \\
Sign. & ns & $*$ & $*$ & ns & ns & ns & $*$ & ns & ns \\
\hline
\end{tabular}

Tab. V. Number of males, females (total and ovigerous) and total individuals of Armases angustipes (Dana, 1852) and results of the $\chi^{2}$ by sampling months, at the mangrove of Mamucabas River, state of Pernambuco, northeast Brazil.

\begin{tabular}{|c|c|c|c|c|c|}
\hline \multirow{2}{*}{ Month } & \multirow{2}{*}{$\hat{0}$} & \multicolumn{2}{|c|}{ ㅇ } & \multirow{2}{*}{ Total } & \multirow{2}{*}{$\chi^{2}$} \\
\hline & & Total & Ovigerous & & \\
\hline Apr/2008 & 2 & 4 & 0 & 6 & 0.67 \\
\hline May/2008 & 12 & 20 & 0 & 32 & 2 \\
\hline Jun/2008 & 15 & 8 & 0 & 23 & 2.13 \\
\hline $\mathrm{Jul} / 2008$ & 7 & 7 & 0 & 14 & 0 \\
\hline Aug/2008 & 5 & 9 & 0 & 14 & 1.14 \\
\hline Sep/2008 & 4 & 9 & 0 & 13 & 1.92 \\
\hline Oct/2008 & 5 & 4 & 0 & 9 & 0.11 \\
\hline Nov/2008 & 2 & 5 & 0 & 7 & 1.29 \\
\hline $\mathrm{Dec} / 2008$ & 8 & 16 & 0 & 24 & 2.67 \\
\hline Jan/2009 & 12 & 5 & 1 & 18 & 2 \\
\hline $\mathrm{Feb} / 2009$ & 11 & 9 & 1 & 21 & 0.05 \\
\hline Mar/2009 & 7 & 10 & 1 & 18 & 0.89 \\
\hline Total & 90 & 106 & 3 & 199 & 1.81 \\
\hline
\end{tabular}

Tab. VI. Correlation of the abiotic data (rainfall air, atmospheric pressure, relative humidity, sunlight, wind speed, air temperature, river salinity, burrow temperature, burrow salinity,) with the abundance of Armases angustipes (Dana, 1852), at the mangrove of Ariquindá River, state of Pernambuco, northeast Brazil (ns, no significant difference).

\begin{tabular}{lccccccccc}
\hline \multirow{2}{*}{ Correlation } & \multicolumn{8}{c}{ Abiotic data } \\
\cline { 2 - 10 } & Rainfall & Atm. pressure & Relative humidity & Sunlight & Wind speed & Air temp. & River salinity & Burrow temp. Burrow salinity \\
\hline$r$ (Pearson) & -0.27 & 0.31 & 0.24 & -0.32 & -0.04 & 0.09 & -0.32 & 0.21 & -0.41 \\
$\mathrm{~T}$ & -0.90 & 1.01 & 0.79 & -1.05 & -0.12 & 0.28 & -1.05 & 0.67 & -1.40 \\
$\mathrm{P}$ & 0.39 & 0.33 & 0.45 & 0.32 & 0.91 & 0.79 & 0.32 & 0.52 & 0.19 \\
Correlation & weak & regular & weak & regular & weak & weak & regular & weak & regular \\
Significance & ns & ns & ns & ns & ns & ns & ns & ns & ns \\
\hline
\end{tabular}

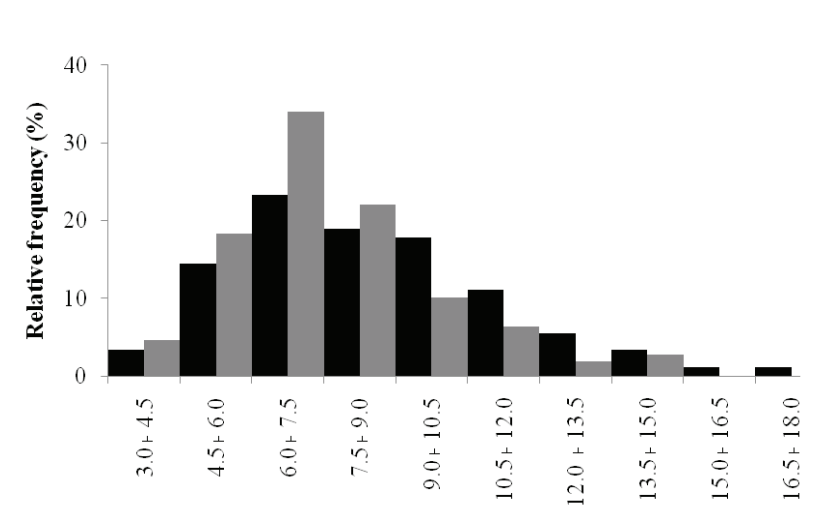

Size classes $(\mathrm{CW}-\mathrm{mm})$

- Males -Females

Fig. 2. Relative frequency (\%) of individuals of Armases angustipes (Dana, 1852) by size of carapace width (CW), at the mangrove of Ariquindá River, state of Pernambuco, northeast Brazil.
\& Coelho, 2011; Araújo et al., 2012c; Oliveira et al., 2013). In few species of Brachyura, females are larger than males, as in the members of Cryptochiridae (UTINOMI, 1944) and in Uca thayeri (ARAújo et al., 2012b), which according to these last authors, may be an adaptation to increase the production of eggs. Finally, in some other studies with Brachyura, both sexes have the same size, as in Ucides cordatus (ARAújo \& CALAdo, 2008), Uca (Leptuca) leptodactyla Rathbun, 1898 (Ocypodidae), Uca (Leptuca) uruguayensis Nobili, 1901 and Uca (Minuca) vocator (Herbst, 1804) (BEDÊ et al., 2008). The similar sizes of males and females observed herein in A. angustipes can be related to the assortative pairing of the individuals for the copula. Assortative mating occurs when individuals with similar genotypes and/or phenotypes copulate with each other frequently. Assortative pairing by size is one of the most common mating in natural populations (CRESPI, 1989) and it was observed in species of crustaceans, as Trapezia bidentata (Forskål, 1775) (Trapeziidae) by ADAMs et al. (1985) and especially in Crustacea Peracarida (AdAms \& 
GreENwOOD, 1987). It is considered a strategy to strengthen the mating bond, thus increasing fertility.

Despite of the proximity of Ariquindá and Mamucabas Rivers, there was a difference on the sexual dimorphism between the mangroves, as discussed above. Factors such as food availability, environmental impacts, among others, are responsible for variations in the community biodiversity between relatively nearby areas (Boschi, 2000; Ashton et al., 2003; Bertini et al., 2004), and that might happens also with some population characteristics.

In both populations of $A$. angustipes analyzed in the present study, the sex ratio did not vary from the Mendelian proportion, but it showed a deviation to the females. According to WenNer (1972), few species of crabs have a sex ratio of $1: 1$. In many natural populations, the sex ratio is close to $1: 1$, but the analysis of temporal variation can evidence some significant differences in some months of the year, such as observed in U. cordatus (ARAúJO \& CALADO, 2008), Grapsus grapsus (Linnaeus, 1758) (Grapsidae) (Freire et al., 2011), S. rectum (CASTIGLIoni et al., 2011b) and C. danae (AraÚJo et al., 2012a). In the present study, at the mangrove of Ariquindá River, females were more abundant than males in October, and at Farol Island males were more abundant in May (KowALCZUK \& MASUNARI, 2000b), for the same species. These variations probably occurred due to cyclic events that act distinctly on individuals of each sex, such as molt, reproduction and migration (ARAúJo et al., 2012a).

In both studied mangroves, size classes were equally represented by both sexes, which is in accordance with the model proposed by WENNER (1972) and with the observations of KoWALCZUK \& MASUNARI (2000b) on the same species. The distribution by size classes did not follow the Gaussian in both sexes and mangroves. At the mangrove of Ariquindá River, the distribution tended to bimodality, which usually reflects recruitment pulses, and also differential mortality (Díaz \& Conde, 1989; Araújo et al., 2012a). Since the reproduction is seasonal, as it will be discussed later, the recruitment isn't continuous, which may also explain the trends observed in the distribution by classes. On the other hand, at the mangrove of Mamucabas River, the distribution was unimodal. This type of distribution is usually related to the continuous reproduction, recruitment and mortality rates in the population (Díaz \& Conde, 1989; Hartnoll \& Bryant, 1990; Castiglioni et al., 2011b), i.e., to a stable population, but in the case of Mamucabas River, it is difficult to affirm this relation, since the number of crabs sampled in this area was very low.

The ovigerous females of $A$. angustipes only occurred in some months of the year, especially in the summer, at both mangroves. In many crustaceans, the reproductive period is programmed to occur in the seasons with the best conditions for larval survival and post larval recruitment (Pillay \& Ono, 1978; Díaz \& Conde, 1989; Сово, 2002a,b; LiRA et al., 2012). Probably, the higher phytoplankton primary productivity observed in the summer favors the breeding activity, since these algae serve as food resource to the decapod larvae (Boolootian et al., 1959; SASTRY, 1983; EMmerson, 1994; CASTiglioni et al., 2007). In Northeastern Brazil, the phytoplankton production is mainly affected by the suspended material on the surface water, lower in the summer; in this period, the photic layer is deeper and, as a consequence, the phytoplankton production is more intense (RESURREIÇ̃̃o et al., 1996; Passavante \& Feitosa, 2004).

The reproduction of $A$. angustipes was characterized as seasonal. In general, at tropical areas, the reproduction tends to be continuous, and with the increase in latitude, it becomes seasonal (PinheIro \& Fransozo, 2002). However, several studies conducted with terrestrial and semi terrestrial crabs show that the most distant from the water level, more defined will be their reproductive cycle. Such fact was observed in Cardisoma guanhumi Latreille, 1825 by Botelno et al. (2001) at the mangrove of Una River, state of Pernambuco, Brazil, in Neosarmatium meinerti (de Man, 1887) (Sesarmidae) by EMMERSON (1994), at South Africa, and in A. angustipes in the present study.

The low number ovigerous females observed in the present study is not an uncommon pattern among crabs (Seiple \& Salmon, 1987; Mantelatto \& Fransozo, 1997; Negreiros-Fransozo et al., 2002; Pinheiro \& Fransozo, 2002; Silva \& Oshiro, 2002; Сово \& Fransozo, 2003; Mantelatto et al., 2003; Lima et al., 2006; CASTIGLIONi et al., 2007; CÉsAR et al., 2007; LiRA et al., 2013). This can be related to the cryptic habit of the ovigerous females. According to LiRA et al. (2013), additional effort to catch these females is not recommended, because it would alter the determination of the breeding period. Thus, the low abundance of ovigerous females offers valuable information to comprehend the reproduction of a given species.

The semi terrestrial crustaceans are influenced by great variety of environmental factors, driven both by wind and water (HERRNKIND, 1983). According to ANGER et al. (1990), A. angustipes must be considered a marine species that has only started its transition to terrestrial and freshwater habitats. Probably due to this ongoing transition, the species is both influenced by air and water characteristics. The environmental factors that most influenced the abundance of $A$. angustipes were atmospheric pressure, river salinity and relative humidity at the mangrove of Ariquindá River, and burrow salinity at the mangrove of Mamucabas River. However, KowALCZUK \& MASUNARI (2000b) found that the population of this same species at Farol Island was not influenced by the salinity, which may be related to the different habitat they studied (rocky shore) or it evidences that this population is more adapted to the terrestrial environment than those studied at state of Pernambuco.

Few studies were accomplished regarding the influence of the hydrostatic pressure on shallow and deep sea species of crustaceans (TEAL \& CAREY, 1967; Macdonald \& Teal, 1975; Macdonald \& Gilchrist, 1982). However, there were found no studies on the influence of 


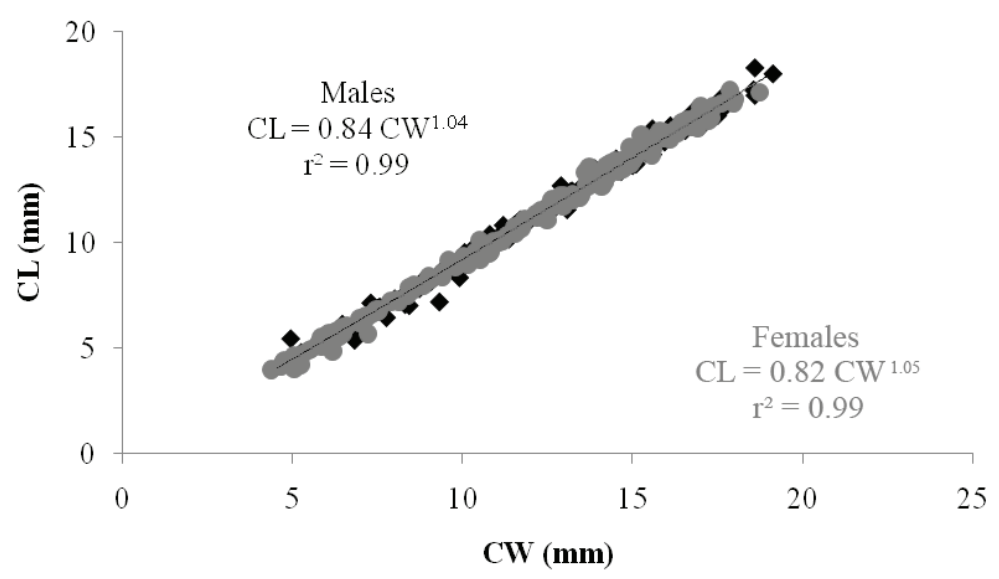

- Males Females

Fig. 3. Relationship between the carapace width (CW) and carapace length (CL) of males and females of Armases angustipes (Dana, 1852) at the mangrove of Ariquindá River, state of Pernambuco, northeast Brazil.

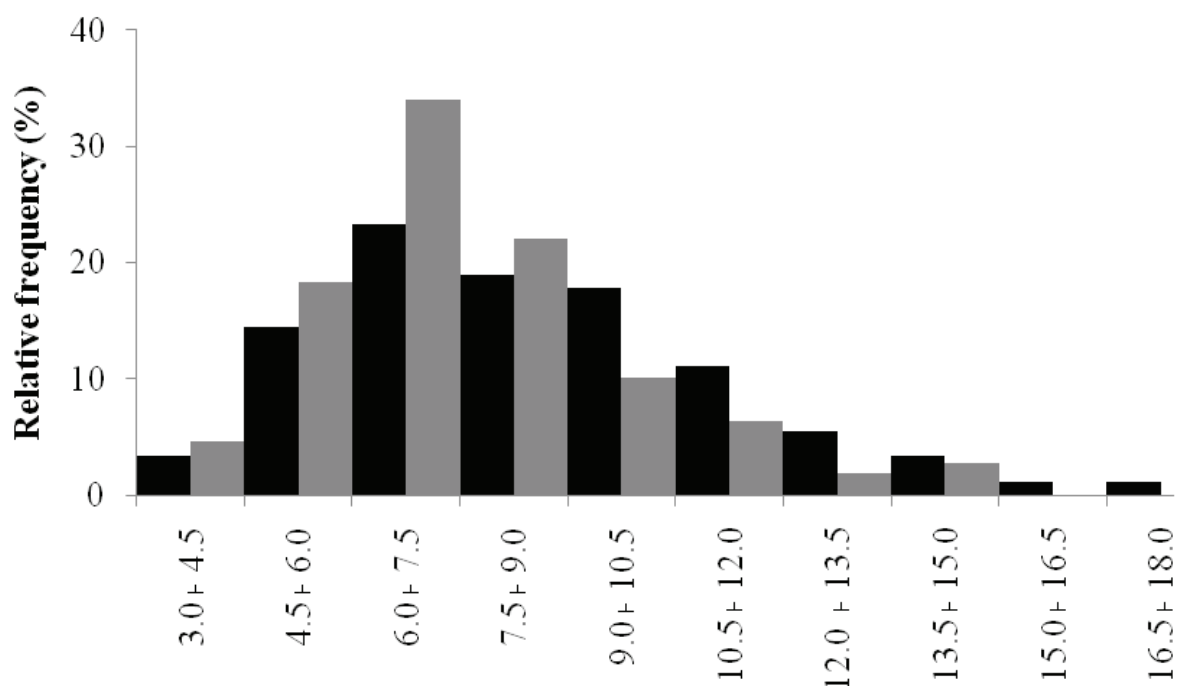

Fig. 4. Relative frequency (\%) of individuals of Armases angustipes (Dana, 1852) by size of carapace width (CW), at the mangrove of Mamucabas River, state of Pernambuco, northeast Brazil.

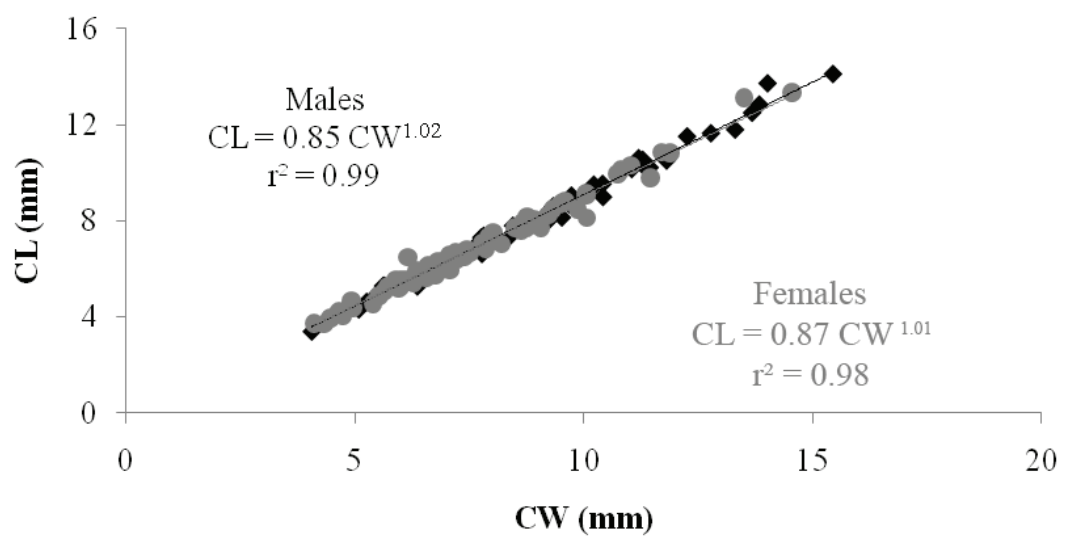

- Males • Females

Fig. 5. Relationship between the carapace width (CW) and carapace length (CL) of males and females of Armases angustipes (Dana, 1852) at the mangrove of Mamucabas River, state of Pernambuco, northeast Brazil. 
the atmospheric pressure on populations of semi terrestrial crustaceans. It is well known that the atmospheric pressure presents daily oscillations due to atmospheric tides (Chapman \& Lindzen, 1970), which are comparable to oceanic tides. This effect is strongest in tropical zones and may influence the terrestrial and semi terrestrial populations. However, further studies are necessary on this feature. More recently, the 'biometeorology' is standing out, searching correlations between meteorological parameters and the organism biology. As the species of crabs that live in mangroves are exposed to the air for much of the day, at low tide, it is possible that beyond hydrologic parameters, meteorological parameters also influence the biology of some of these species. Rainfall influences the salinity (Passavante \& Feitosa, 2004), both of river and burrow water, which affects the physiology of these species. In turn, high humidity can prevent desiccation of the crabs when they are exposed to the air at low tide. However, the influence was inversely proportional, indicating that the relation between air humidity and population aspects needs to be further studied in future work.

The specimens of $A$. angustipes from the mangrove of Ariquindá River population are both larger and wider than those from the mangrove of Mamucabas River. Besides, the abundance of crabs and the frequency of ovigerous females observed at Mamucabas mangrove were lower. Despite of the differences in the salinity of the rivers, we believe that the population of Mamucabas River may be stressed by the environmental impacts that this area has been receiving in the past years. There are evidences to believe it so. At Mamucabas River, the species Laguncularia racemosa (L.) C.F. Gaertn. (Combretaceae) was dominant, a characteristic of environmental unstable mangroves with lower biodiversity, while at the Ariquindá River, Rhizophora mangle L. (Rhizophoraceae) was the dominant species, what is typical from preserved mangroves with higher biodiversity (FromARD et al., 1998; MACINTOSH et al., 2002; Colpo et al., 2011). ARAúso et al. (unpublished data) confirmed this, observing a higher diversity of Brachyura species at the mangrove of Ariquindá River. In addition, in the species $U$. cordatus, the condition factor (parameter of the general "well-being" of a species, indicating its degree of adjustment to the environment) was significantly lower at Mamucabas River, indicating the lower health of the specimens of this estuary (ARAúJo et al., 2012c). The authors related that to the cut off trees, which may reduce the food resource for this species of herbivorous crab. The deforestation observed at the margins of the Mamucabas River (ARAúso et al., 2012b,c) can also be one of the limiting factors for Armases angustipes, since the mangrove trees are one of the microhabitats most visited by the crabs (Melo, 1996). On the other hand, the deposition of solid waste, also observed at Mamucabas River, may benefit the detritivorous species due to the increase in the quantity of organic matter, such as observed for Uca thayeri; males and females of Mamucabas mangrove reached sexual maturity at sizes higher than those of Ariquindá mangrove
(ARAúso et al., 2012b).

The present study is an important contribution to the knowledge of the population biology of Armases angustipes at tropical areas, highlighting the capacity of the species to respond to environmental impacts. That may be an indicative of its potential as a bioindicator, and further studies with this species in other tropical and subtropical areas are still needed.

\section{REFERENCES}

Adams, J.; Edwards, A. J. \& Emberton, H. 1985. Sexual size dimorphism and assortative mating in the obligate coral commensal Trapezia ferruginea Latreille (Decapoda, Xanthidae). Crustaceana 48(2):188194.

Adams, J. \& Greenwood, P. J. 1987. Loading constraints sexual selection and assortative mating in peracarid Crustacea. Journal of Zoology 211(1):35-46.

Alves, R. R. N. \& NishidA, A. K. 2003. Socio-economical aspects and environmental perception of 'Caranguejo-uçá', U. cordatus (L. 1763) (Decapoda, Brachyura) gatherers in the Mamanguape river estuary, northeast Brazil. Interciencia 28(1):36-43.

Anger, K.; Harms, J.; Montú, M. \& BAKKer, C. 1990. Effects of salinity on the larval development of a semiterrestrial tropical crab, Sesarma angustipes (Decapoda: Grapsidae). Marine Ecology Progress Series 62:89-94.

AraúJo, M. S. L. C. \& CALADo, T. C. S. 2008. Bioecologia do caranguejouçá Ucides cordatus (Linnaeus) no Complexo Estuarino Lagunar Mundáu/Manguaba (CELMM), Alagoas, Brasil. Revista da Gestão Costeira Integrada 8(2):169-181.

.2011. Burrows architecture of the crab Ucides cordatus (Linnaeus, 1763) (Crustacea, Decapoda, Ucididae) in a mangrove swamp of Brazil. Tropical Oceanography 39(2):155-165.

Araújo, M. S. L. C.; Barreto, A. V.; Negromonte, A. O. \& Schwamborn, R. 2012a. Population ecology of the blue crab Callinectes danae (Crustacea: Portunidae) in a Brazilian tropical estuary. Anais da Academia Brasileira de Ciências 84(1):129-138.

Araújo, M. S. L. C.; Castiglioni, D. S. \& Coelho, P. A. 2012b. Widthweight relationship and condition factor of Ucides cordatus (Crustacea, Decapoda, Ucididae) at tropical mangroves of Northeast Brazil. Iheringia, Série Zoologia 102(3):277-284.

2012c. Relative growth and determination of morphological sexual maturity of the fiddler crab Uca thayeri Rathbun (Crustacea, Ocypodidae) in two mangrove areas from Brazilian tropical coast. Pan-American Journal of Aquatic Sciences 7(3):156-170.

Araújo, M. S. L. C.; Negromonte, A. O.; Barreto, A. V. \& Castiglioni, D. S. 2012d. Sexual maturity of the swimming crab Callinectes danae (Crustacea: Portunidae) at the Santa Cruz Channel, a tropical coastal environment. Journal of the Marine Biological Association of the United Kingdom 92:287-293.

Ashton, C. A.; Hogarth, P. J. \& Macintosh, D. J. 2003. A comparison of brachyuran crab community structure at four mangrove locations under different management systems along the Melaka StraitsAndaman Sea coast of Malaysia and Thailand. Estuaries 26(6):14611471.

Bedê, L. M.; Oshiro, L. M. Y.; Mendes, L. M. D. \& Silva, A. A. 2008. Comparison of the population structure of the species of Uca (Crustacea: Decapoda: Ocypodidae) in the mangrove of Itacuruçá, Rio Janeiro, Brazil. Revista Brasileira de Zoologia 25(4):601-607.

Benedetto, M. D. \& Masunari, S. 2009. Estrutura populacional de Uca maracoani (Decapoda, Brachyura, Ocypodidae) no Baixo Mirim, Baía de Guaratuba, Paraná. Iheringia, Série Zoologia 99(4):381-389.

Benetti, A. S. \& Negreiros-Fransozo, M. L. 2004. Relative growth of Uca burgersi (Crustacea, Ocypodidae) from two mangroves in the southeastern Brazilian coast. Iheringia, Série Zoologia 94(1):67-72.

Benetti, A. S.; Negreiros- Fransozo, M. L. \& Costa, T. M. 2007. Population and reproductive biology of the crab Uca burgersi (Crustacea: Ocypodidae) in three subtropical mangrove forests. Revista de Biología Tropical 55(1):55-70. 
Bertini, G.; Fransozo, A. \& Melo, G. A. S. 2004. Biodiversity of brachyuran crabs (Crustacea: Decapoda) from non-consolidated sublittoral bottom on the northern coast of São Paulo State, Brazil. Biodiversity and Conservation 13:2185-2207.

Bezerra, L. E. A. \& Matthews-Cascon, H. 2007. Population and reproductive biology of the fiddler crab Uca thayeri Rathbun, 1900 (Crustacea: Ocypodidae) in a tropical mangrove from Northeast Brazil. Acta Oecologica 31:251-258.

Boolootian, R. A. A.; Giese, A. C.; Farmanfarmain, A. \& Tucker, J. 1959. Reproductive cycles of five west coast crabs. Physiological Zoology 32:213-220.

Boschi, E. E. 2000. Species of decapod crustaceans and their distribution in the American marine zoogeographic provinces. Revista de Investigación y Desarrollo Pesquero 13:7-136.

Botelho, E. R. O.; Santos, M. C. F. \& Souza, J. R. B. 2001. Aspectos populacionais do guaiamum, Cardisoma guanhumi Latreille, 1825, do estuário do rio Una (Pernambuco-Brasil). Boletim Técnico Científico do CEPENE 9(1):123-146.

CAladdo, T. C. S. \& LACERDA, P. R. 1993. Zonação vertical e variação sazonal da carcinofauna (Decapoda e Isopoda) do costão rochoso de Calhetas (Cabo-Pernambuco-Brasil). Arquivos de Biologia e Tecnologia 36(4):731-738.

Castiglioni, D. S.; Almeida, A. O. \& Bezerra, L. E. A. 2011a. More common than reported: range extension, size-frequency and sexratio of Uca (Minuca) victoriana (Crustacea: Ocypodidae) in tropical mangroves, Brazil. Marine Biodiversity Records 3(94):1-8.

Castiglioni, D. S. \& Coelho, P. A. 2011. Determinação da maturidade sexual de Ucides cordatus (Crustacea, Brachyura, Ucididae) em duas áreas de manguezal do litoral sul de Pernambuco, Brasil. Iheringia, Série Zoologia 101:138-144.

Castiglioni, D. S.; Negreiros-Fransozo, M. L. \& Cardoso, C. F. 2007. Breeding season and molt cycle of the fiddler crab Uca rapax (Brachyura: Ocypodidae) in a subtropical estuary, Brazil, South America. Gulf and Caribbean Research 19:11-20.

Castiglioni, D. S.; Negreiros-Fransozo, M. L. \& Mortari, R. C. 2006. Biologia populacional do caranguejo violinista Uca rapax (Smith, 1870) (Crustacea, Ocypodoidea), proveniente de uma área de manguezal degradado em Paraty, RJ, Brasil. Atlântica 28(2):73-86.

Castiglioni, D. S.; Silva, J. V. C. L. \& Azevedo, D. S. 2011b. Relative growth and its use to determine the morphological sexual maturity of Ucides cordatus (Linnaeus, 1763) (Decapoda, Brachyura, Ucididae) from two mangrove areas on the Northeastern Brazilian coast. Crustaceana 84:1221-1241.

César, I. I.; Armendariz, L. C. \& Becerra, R. V. 2007. Fecundity of Uca uruguayensis and Chasmagnathus granulatus (Decapoda, Brachyura) from the "Refúgio de Vida Silvestre", Bahía Samborombón, Argentina. Brazilian Journal of Biology 67:749-753.

Chapman, S. \& Lindzen, R. S. 1970. Atmospheric tides: thermal and gravitational. New York, Gordon and Breach. 200p.

Сово, V. J. 2002a. Breeding period of the arrow crab Stenorhynchus seticornis from Couves Island, south-eastern Brazilian coast. Journal of the Marine Biological Association of the United Kingdom 82(6):1031-1032.

2002b. Breeding period of the spider crab Mithraculus forceps (A. Milne Edwards) (Crustacea: Majidae: Mithracinae) in the southeastern Brazilian coast. Revista Brasileira de Zoologia 19(1):229-234.

CoBo, V. J. \& Fransozo, A. 2003. External factors determining breeding season in the red mangrove crab Goniopsis cruentata (Latreille) (Crustacea: Brachyura: Grapsidae) on the São Paulo state northern coast, Brazil. Revista Brasileira de Zoologia 20:213-217.

CoеLho, P. A. 1965/1966. Os crustáceos decápodos de alguns manguezais pernambucanos. Trabalhos do Instituto Oceanográfico da Universidade Federal de Pernambuco 7(8):71-90.

Coelho, P. A. \& Ramos-Porto, M. 1981. Grapsidae do gênero Sesarma do Norte e Nordeste do Brasil (Crustacea, Decapoda) com especial referência a Pernambuco. Anais do III Encontro de Zoologia do Nordeste, Recife. p. 176-185.

1995. Crustáceos da região de Tamandaré, Estado de Pernambuco, Brasil. Boletim Técnico-Científico do CEPENE 3(1):57-80.
Colpo, K. D.; Chacur, M. M.; Guimarães, F. J. \& Negreiros-Fransozo, M. L. 2011. Subtropical Brazilian mangroves as a refuge of crab (Decapoda: Brachyura) diversity. Biodiversity Conservation 20:3239-3250.

Costa, T. M. \& Negreiros-Fransozo, M. L. 2003. Population biology of Uca thayeri Rathbun, 1900 (Brachyura, Ocypodidae) in a subtropical South American mangrove area: results from transect and catch per unit effort techniques. Crustaceana 75(10):1201-1218.

Cowen, R. K. 1986. Site-specific differences in the feeding ecology of the California sheepbead, Semicossyphus pulcher (Labridae). Environmental Biology of Fishes 16(1):193-203.

CPRH. 1999. Diagnóstico sócio-ambiental e ZEEC - Zoneamento Ecológico Econômico Costeiro Litoral sul de Pernambuco. Recife, Companhia Pernambucana do Meio Ambiente/GERCO. 91p. . 2003. Diagnóstico sócio-ambiental do litoral sul de Pernambuco. Recife, Companhia Pernambucana do Meio Ambiente/GERCO. 87p.

Crespi, B. J. 1989. Causes of assortative mating in arthropods. Animal Behavior 38:980- 1000.

Díaz, H. \& Conde, J. E. 1989. Population dynamics and life of mangrove crab Aratus pisonii (Brachyura, Grapsidae) in a marine environment. Bulletin of Marine Science 45:148-163.

Emmerson, W. D. 1994. Seasonal breeding cycles and sex ratios of eight species of crabs from Mgazana, a mangrove estuary in Transkei, Southern Africa. Journal of Crustacean Biology 14(3):568-578.

Freire, A. S.; Pinheiro, M. A. A.; Karam-Silva, H. \& Teschima, M. M. 2011. Biology of Grapsus grapsus (Linnaeus, 1758) (Brachyura, Grapsidae) in the Saint Peter and Saint Paul Archipelago, Equatorial Atlantic Ocean. Helgoland Marine Research 65(3):263-273.

Freitas, A. E. T. \& Santos, M. C. F. 2002. Aspectos biológicos do aratuda-pedra Plagusia depressa (Fabricius, 1775) (Crustacea: Brachyura, Grapsidae) ao largo de Tamandaré (Pernambuco - Brasil). Boletim Técnico Científico do CEPENE 10(1):1-17.

Fromard, F.; Puig, H.; Mougin, E.; Marty, G.; Betoulle, J. L. \& Cadamuro, L. 1998. Structure, above-ground biomass and dynamics of mangrove ecosystems: new data from French Guiana. Oecologia 115(1):39-53.

Góes, P.; Sampaio, F. D. F.; Carmo, T. M. S.; Tôso, G. C. \& Leal, M. S. 2000. Comportamento e período reprodutivos do caranguejo do mangue Ucides cordatus. Anais do V Simpósio de Ecossistemas Brasileiros Conservação 2:335-348.

Grego, C. K. S.; Feitosa, F. A. N.; Silva, M. H.; Cunha, M. G. G. S. \& Nascimento-Filho, G. A. 2009. Fitoplâncton do ecossistema estuarino do Rio Ariquindá (Tamandaré, Pernambuco, Brasil): variáveis ambientais, biomassa e produtividade primária. Atlântica 31(2):183-198.

Hartnoll, R. G. \& Bryant, A. D. 1990. Size-frequency distributions in Decapod Crustacea - The quick, the dead, and the castoffs. Journal of Crustacean Biology 10(1):14-19.

Hemmi, J. M.; Marshall, J.; Pix, W.; Vorobyev, M. \& Zeil, J. 2006. The variable colours of the fiddler crab Uca vomeris and their relation to background and predation. Journal of Experimental Biology 209:4140-4153.

Herreid, C. F. 1963. Observations on the feeding behavior of the Cardisoma guanhumi (Latreille) in Southern Florida. Crustaceana 5(3):176-180.

HerRnKInd, W. F. 1983. Movement patterns and orientation. In: BuIss, D. ed. The biology of Crustacea. New York, Academic Press. p. 41-105.

HuXLEY, J. S. 1950. Relative growth and form transformation. Proceedings of the Zoological Society of London 137:465-469.

IBAMA. 1989. Unidades de conservação do Brasil. Parques Nacionais e Reservas Biológicas. Brasília, Instituto Brasileiro do Meio Ambiente e dos Recursos Naturais Renováveis. p. 151-153.

Ivo, C. T. C.; Dias, A. F. \& MotA, R. I. 1999. Estudo sobre a biologia do caranguejo uçá Ucides cordatus cordatus (Linnaeus, 1763) capturado no Delta do Parnaíba, Estado do Piauí. Boletim Técnico-Científico do CEPENE 7(1):53-84.

KowalczuK, V. G. L. \& Masunari, S. 2000a. Crescimento relativo e determinação da idade na fase juvenil de Armases angustipes (Dana, 1852) (Decapoda: Brachyura: Grapsidae). Revista Brasileira de Zoologia 17(1):17-24. 
2000b. Estrutura populacional de Armases angustipes (Dana) (Decapoda, Brachyura, Grapsidae) na Ilha do Farol, Matinhos, Paraná. Revista Brasileira de Zoologia 17(1):1-16.

Lima, G. V.; Soares, M. R. S. \& Oshiro, L. M. Y. 2006. Reproductive biology of the sesarmid crab Armases rubripes (Decapoda: Brachyura) from an estuarine area of the Sahy river, Sepetiba Bay, Rio de Janeiro, Brazil. Iheringia, Série Zoologia 96:47-52.

Lira, J. J. P. R.; Calado, T. C. S \& AraúJo, M. S. L. C. 2012. Condition factor of Goniopsis cruentata (Crustacea, Brachyura, Grapsidae) from Mundaú/Manguaba estuarine complex, Alagoas, Brazil. Iheringia, Série Zoologia 102(3):285-291.

.2013. Breeding period in the mangrove crab Goniopsis cruentata (Decapoda: Grapsidae) in Northeastern Brazil. Revista de Biología Tropical 61:29-38.

MacDonald, A. G. \& Gilchist, I. 1982. The pressure tolerance of deep sea amphipods collected at their ambient high pressure. Comparative Biochemistry and Physiology Part A: Physiology 71(2):349-352.

MacDonald, A. G. \& Teal, J. M. 1975. Tolerance of oceanic and shallow water Crustacea to high hydrostatic pressure. Deep Sea Research and Oceanographic Abstracts 22(3):131-144.

Maciel, D. C. \& Alves, A. G. 2009. Conhecimentos e práticas locais relacionados ao aratu Goniopsis cruentata (Latreille, 1803) em Barra de Sirinhaém, litoral sul de Pernambuco, Brasil. Biota Neotropica 9(4):29-36.

Macintosh, D. J.; Ashton, E. C. \& Havanon, S. 2002. Mangrove rehabilitation and intertidal biodiversity: a study in the Ranong mangrove ecosystem, Thailand. Estuarine, Coastal and Shelf Science 55(3):331-345.

Mantelatto, F. L. M.; Faria, F. C. R. \& Garcia, R. B. 2003. Biological aspects of Mithraculus forceps (Brachyura: Mithracidae) from Anchieta Island, Ubatuba, Brazil. Journal of the Marine Biological Association of the United Kingdom 83:789-791.

Mantelatto, F. L. M. \& Fransozo, A. 1997. Fecundity of the crab Callinectes ornatus Ordway 1863 (Decapoda, Brachyura, Portunidae) from the Ubatuba region, São Paulo, Brazil. Crustaceana 70:214-226.

Martin, J. W. \& Davis, G. E. 2001. An updated classification of the recent Crustacea. Natural History Museum of Los Angeles County, Science Series 39:1-124.

Melo, G. A. S. 1996. Manual de identificação dos Brachyura (caranguejos, siris) do litoral brasileiro. São Paulo, Plêiade FAPESP. 604p.

Menezes, A. P. D.; Araújo, M. S. L. C. \& Calado, T. C. S. 2012. Bioecologia de Goniopsis cruentata (Latreille, 1803) (Decapoda, Grapsidae) do complexo estuarino-lagunar Mundaú/Manguaba, Alagoas, Brasil. Natural Resources 2:37-49.

Moura, R. T. \& Passavante, J. Z. O. 1995. Biomassa fitoplanctônica na baía de Tamandaré, Rio Formoso - Pernambuco, Brasil. Trabalhos Oceanográficos da Universidade Federal de Pernambuco 23:1-15.

Negreiros-Fransozo, M. L.; Fransozo, A. \& Bertini, G. 2002. Reproductive cycle and recruitment period of Ocypode quadrata (Decapoda: Ocypodidae) at a Sandy beach in southeastern Brazil. Journal of Crustacean Biology 22:157-161.

NG, P. K.; Guinot, D. \& DAvIE, P. J. 2008. Systema Brachyurorum: Part I. An annotated checklist of extant brachyuran crabs of the world. The Raffles Bulletin of Zoology 17:1-286.

Oliveira, P. J. A.; Coelho, P. A. \& Castiglioni, D. S. 2013. Population biology of Ucides cordatus (Linnaeus, 1763) (Crustacea, Brachyura, Ucididae) from two tropical mangroves sites in northeast coast of Brazil. Pan-American Journal of Aquatic Sciences 8(2):89-103.

Passavante, J. Z. O. \& Feitosa, F. A. N. 2004. Dinâmica da produtividade fitoplanctônica na zona costeira. In: Eskinazi-LeÇA, E.; NeumanNLeITÃo, S. \& CostA, M. F. eds. Oceanografia: Um Cenário Tropical. Recife, Bagaço. p. 425-439.
Passioura, J. B.; Ball, M. C. \& Knight, J. H. 1992. Mangroves may salinize the soil and in so doing limit their transpiration. Functional Ecology 6:476-481.

Pillay, K. K. \& Ono, Y. 1978. The breeding cycles of two species of Grapsidae crabs (Crustacea, Decapoda) from the north coast of Kyushu, Japan. Marine Biology 45:237-248.

Pinheiro, M. A. A. \& Fransozo, A. 2002. Reproduction of the speckled swimming crab Arenaeus cribrarius (Brachyura Portunidae) on the Brazilian coast near $23^{\circ} 30^{\prime} \mathrm{S}$. Journal Crustacean Biology 22(2):416-428.

Resurreição, M. G.; Passavante, J. Z. O. \& Macedo, S. J. 1996. Estudo da plataforma continental na área do Recife (Brasil): variação sazonal da biomassa fitoplanctônica $\left(08^{\circ} 03^{\prime} 38^{\prime \prime}\right.$ Lat. S; $34^{\circ} 42^{\prime} 28^{\prime \prime}$ à $34^{\circ} 52^{\prime} 00^{\prime \prime}$ Long. W). Trabalhos Oceanográficos da UFPE 24:39-59.

SAmpedro, M. P.; GonZÁlez-GurriarÁn, E.; Freire, J. \& MuiÑo, R. 1999. Morphometry and sexual maturity in the spider crab Maja squinado (Decapoda: Majidae) in Galicia, Spain. Journal of Crustacean Biology 19(3):578-592.

Santos, M. C. F. \& Botelho, E. 2002. Estudos biológicos do aratú, Goniopsis cruentata (Latreille, 1803) (Crustacea: Decapoda: Grapsidae) no estuário do rio Una, município de São José da Coroa Grande (Pernambuco-Brasil). Boletim Técnico Científico do CEPENE 10:171-186.

Santos, M. C. F.; Botelho, E. R. O. \& Ivo, C. T. C. 2001. Biologia populacional e manejo da pesca de aratu, Goniopsis cruentata (Latreille, 1803) (Crustacea: Decapoda: Grapsidae) no litoral sul de Pernambuco-Brasil. Boletim Técnico Científico do CEPENE 9(1):87-123.

SASTRY, A. 1983. Ecological aspects of reproduction. In: Buiss, D. ed. The biology of Crustacea. New York, Academic Press, p. 179-269.

Schubart, C. D. \& Diesel, R. 1998. Osmoregulatory capacities and penetration into terrestrial habitats: a comparative study of Jamaican crabs of the genus Armases Abele, 1992 (Brachyura: Grapsidae: Sesarminae). Bulletin of Marine Science 62(3):743-752.

Seiple, W. H. \& Salmon, M. 1987. Reproductive, growth and life-history between two species of grapsid crabs, Sesarma cinereum and $S$. reticulatum. Marine Biology 94:1-6.

Silva, Z. S. \& Oshiro, L. M. Y. 2002. Aspectos reprodutivos de Goniopsis cruentata (Latreille) (Crustacea, Brachyura, Grapsidae) na Baía de Sepetiba, Rio de Janeiro, Brasil. Revista Brasileira de Zoologia 19:907-914.

Sturges, H. A. 1926. The choice of a class interval. Journal of the American Statistical Association 21(153):65-66.

TEAL, J. M. \& CAREY, F. G. 1967. Effects of pressure and temperature on the respiration of euphausiids. Deep Sea Research and Oceanographic Abstracts 14(6): 725-733.

Thongtham, N. \& Kristensen, E. 2003. Physical and chemical characteristics of mangrove crab (Neoepisesarma versicolor) burrows in the Bangrong mangrove forest, Phuket, Thailand with emphasis on behavioral response to changing environmental conditions. Vie et Milieu 53:141-151.

Utinomi, H. 1944. Studies on the animals inhabiting reef corals. III. A revision of the family Hapalocarcinidae (Brachyura) with some remarks on their morphological peculiarities. Palao Tropical Biological Station Studies 2(4):687-731.

Wenner, A. M. 1972. Sex ratio as a function of size in marine Crustacea. American Naturalist 106(949):321-350.

ZAR, J. H. 1996. Biostatistical analysis. Upper Saddle River, Prentice Hall. 663 p. 